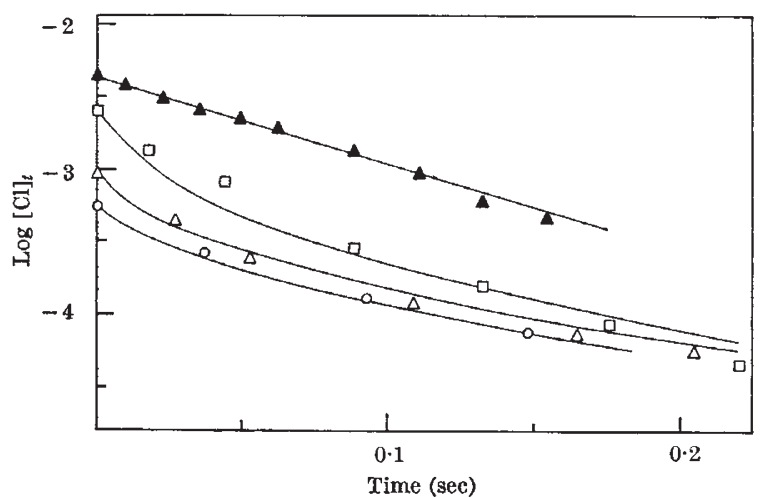

Fig. 1. Variation of $\log ^{-}[\mathrm{Cl}]_{t}$ with time, using 100 per cent chlorine. The points are experimental; the lines are theoretical (equation (1))

the probable range of values for the rate constant is 3-12 $\times 10^{14}$ c.c. $^{2}$ mole $^{-2}$ sec $^{-1}$.

From the experiments with argon/chlorine mixtures the qualitative conclusion can be drawn that argon is less efficient as a third body than chlorine for the recombination reaction; the observed reaction order remained ono for all mixtures, and with particular significance for those having a high total pressure but a low partial pressure of chlorine.

The first-order rate constant, $k_{w}$, was found to vary inversely with the total pressure, implying control by radial diffusion. Using a calculated value for the diffusion coefficient $^{2}$ this would not be expected; the calculated coefficient for chlorine atoms may therefore be too high. Ogryzlo gives a value of $4 \times 10^{-5}$ for $\gamma$, the surface recombination coefficient. In the present experiments, $\gamma$ was probably of the order of $10^{-3}$, but this could not be determ. ined reliably since the first-order rate constant was not found to be independent of pressure. Further work is being carried out in this laboratory.

We thank the U.S. Office of Aerospace Research for providing some of the equipment used during this work (grant No. AF.EOAR 63-32).

Inorganic Chemistry Laboratory,

$$
\text { J. W. LINNETT }
$$$$
\text { M. Н. Воотн }
$$

University of Oxford.

${ }^{1}$ Ogryzlo, E. A., Canad. J. Chem., 39, 2556 (1961).

${ }^{2}$ Andrussov, L., Z. Elektrochemie, 54, 566 (1950).

\section{Hydrogen - Air Fuel Cell with Homogeneous Oxidation Catalyst Redox Cycle}

Is fuel cells with an intermediate redox cycle, electrochemical reactants are prepared by the action of a fuel and an oxidant on a rodox system. Complexes of copper in certain organic solvents present particularly interesting systems. For example, cupric acetate dissolved in pyridine oxidizes molecular hydrogen; cuprous acetate is the homogeneous catalyst as well as the reaction product ${ }^{1,2}$. In air, the reverse reaction proceeds with ease. Such systems may be useful in fuel cells operating on air and hydrogen as they would avoid the troublesome problem of maintaining the gas/electrolyte boundary in a specific position in the porous electrodes.

I carried out experiments to estimate the properties of such a system. Hydrogen at $95^{\circ} \mathrm{C}$ and atmosphoric pressure reduced a $0.2 \mathrm{M}$ solution of cupric acetate in pyridine without the formation of copper metal. Cells composed of platinum/copperII/pyridine acetate/copperI/ platinum, where copperII and copperI stand for the solutions of the corresponding acetates in pyridine, yielded $0 \cdot 21-0.24 \mathrm{~V}$ at $95^{\circ} \mathrm{C}$. With a silver anode the potentials were $0.01-0.03 \mathrm{~V}$ higher. Carbon dioxide and carbon monoxide did not affect the anode potential. Hence the system should be able to utilize hydrogen from water gas, or hydrocarbon-reforming gas, without need for prior removal of carbon oxides. After polarization by drawing currents, the potential recovered readily. The potential of the cathode was $0.06 \mathrm{~V}$ noble versus a saturatep calomel electrode, measured by disregarding liquid junction potentials that may be associated with the pyridine acetate bridge.

Although the potential of this cell was low, compared with $0.95-1 \cdot 10 \mathrm{~V}$ for direct hydrogen-oxygen fuel cells, other complexing and solvent media may give more favourable potentials.

\section{A. Dravnieks}

IIT Research Institute*, Chicago, Illinois.

* Formerly Armour Research Foundation of Illinois Institute of Tech. nology.

1 Wright, L. W., Weller, S., and Mills, G. A., J. Phys. Chem., 59, 1060 (1955).

2 Dakers, R. G., and Halpern, J., Canad. J. Chem., 32, 969 (1954).

\section{BIOCHEMISTRY}

\section{Blood Corticosterone-levels in the Rat after Administration of Amino-acids}

Munro and Mukerji ${ }^{1}$ observed that the feeding of single large doses of certain individual amino-acids, notably glycine, methionine and leucine, caused a marked stimulation of uptake of phosphorus-32 by rat-liver ribonucleic acid (RNA) during the next $18 \mathrm{~h}$. In the case of methionine and leucine, but not of glycine, this action was abolished by adrenalectomy ${ }^{2}$. It was therefore proposed that the increased incorporation of phosphorus-32 into liver RNA after feeding methionine or leucine was due to release of adrenocortical hormones, which are known to induce changes in liver RNA metabolism ${ }^{3}$. The experimonts reported here show that, within a 24 -h period of administering methionine or leucine to rats, there is an elevation of blood corticosterone-level. Administration of other amino-acids or of casein does not have this effect. These observations would thus appear to confirm the proposed mechanism of action of methionine and leucine on liver RNA metabolism.

Male rats weighing about $150 \mathrm{~g}$, trained ${ }^{1}$ to consume food promptly, were fed a meal containing $2 \mathrm{~g}$ of a starchglucose mixture ${ }^{1}$ and $1 \mathrm{~g}$ of an amino-acid (glycine, methionine, leucine, alanine, aspartic acid or glutamic acid) or casein; control animals received the starchglucose mixture without any addition. All animals were, killed $24 \mathrm{~h}$ later by guillotine and corticosterone concentrations in the plasma and the adrenal glands were measured fluorometrically with an Aminco-Bowman spectrophotofluorometer.

Table 1. Corticosteroid-Levels in Plasma and Adrenat Gland $24 \mathrm{H}$ AFTER FEEDING INDIVIDUAL AMINO-ACIDS OR CASEIN IN 1-G QUANTITIES

$\begin{array}{lcc}\begin{array}{c}\text { Addition to } \\ \text { carbohydrate meal }\end{array} & \begin{array}{c}\text { Corticosterone con- } \\ \text { centration in plasma }\end{array} & \begin{array}{c}\text { Corticosterone concen- } \\ \text { tration in adrenal gland }\end{array} \\ \text { Casein } & 86 & 110 \\ \text { Glycine } & 85 & 110 \\ \text { Methionine } & 125 & 139 \\ \text { Leucine } & 107 & 131 \\ \text { Alanine } & 80 & 122 \\ \text { Aspartic acid } & 82 & 119 \\ \text { Glutamic acid } & 76 & 108 \\ \text { Byanalysis of variance } & P<0.01 & P>0.05 \\ \text { Fiducial limits } & 28 & -\end{array}$

The results are expressed as a percentage of corticosterone concentration found in plasma or gland $24 \mathrm{~h}$ after feeding the carbohydrate meal alone.

The control animals fed only the carbohydrate meal had high levels of corticosterone in the plasma (mean level $126 \mu \mathrm{g} / 100 \mathrm{ml}$. plasma) and in the adrenal glands (mean concentration $9 \cdot 5 \mu \mathrm{g} / 100 \mathrm{mg}$ adrenal tissugl onmoan, the values reported in the literature ${ }^{4.5}$ alaken's 